\title{
First report on molecular basis of potato leaf roll virus (PLRV) aggravation by combined effect of tuber and prevailing aphid
}

\author{
Ravi Ranjan Kumar ${ }^{1}$, Mohammad Ansar ${ }^{2}$, Kumari Rajani $^{3}$, Jitesh Kumar ${ }^{1}$ and Tushar Ranjan ${ }^{\text {* }}$ (1)
}

\begin{abstract}
Objective: The Potato Leaf Roll Virus (PLRV) is one of the most devastating virus causing severe yield losses worldwide in potato. The comprehensive observations were made to study the PLRV infestation in major potato growing areas of Bihar (India) and further detailed molecular basis of PLRV aggravation was established.

Results: Although aphids population were found comparatively lower with maximum symptomatic plants, our molecular data further confirms the presence of PLRV in all possible symptomatic tissues such as tubers, shoots and leaves. For the first time, we have proposed molecular basis of aggravation of PLRV, where tuber acts as a reservoir during off-season and further transmitted by aphids.
\end{abstract}

Keywords: Potato leaf roll virus (PLRV), Tuber, Reservoir, Aphid, Virus transmission

\section{Introduction}

The potato crop is severely affected by various biotic stresses and among which viruses play a significant contribution in terms of huge loss in crop yield worldwide including India. Potato is affected by deadly viruses especially more potential infection via seed tubers due to the vegetative reproduction of the crop. More than 40 viruses and viroids hamper the cultivation of potato across the globe $[1,2]$. The crop is infected by more than 30 RNA viruses, out of which 13 are mainly transmitted by aphids. Potato leaf roll virus (PLRV), belongs to genus Polerovirus and family Luteoviridae, is a widely spread potato virus worldwide and responsible for more than 20 million tonnes yield loss (up to 90\%) globally [3]. PLRV is the only transmitted by aphids, namely, Myzus persicae. It is widely multiplied in the phloem tissue and the symptoms of disease reflect this position [4]. Because potato is

\footnotetext{
*Correspondence: mail2tusharranjan@gmail.com

${ }^{1}$ Department of Molecular Biology and Genetic Engineering, Bihar

Agricultural University, Sabour, Bhagalpur 813210 , India

Full list of author information is available at the end of the article
}

a vegetatively propagated crop, once it gets infected with viruses, they can easily disseminate in the progeny tubers. These viruses are found in single or most of the time as a mixed infection within the potato crops. Tubers used for planting in next season can harbor latent viruses that subsequently reduce emergence, plant vigor and yield. All daughter tubers produced by infected mother tubers (secondary infection) will also get infected via systemic translocation of the virus during growth $[5,6]$. Although, potato leaf roll disease is widespread throughout India but it is extremely critical in eastern plain zone, where population of vectors are very high in mid-February and March. In subsequent months, the higher temperature does not support the survival and growth of the aphids, makes them unavailable for potato host plants which ultimately breaks the leaf roll disease cycle. But in the subsequent season, infected tubers may provide primary inoculum which further spread aphids and thus affect the crop severely.

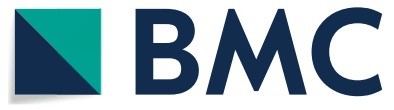

(c) The Author(s) 2020. This article is licensed under a Creative Commons Attribution 4.0 International License, which permits use, sharing, adaptation, distribution and reproduction in any medium or format, as long as you give appropriate credit to the original author(s) and the source, provide a link to the Creative Commons licence, and indicate if changes were made. The images or other third party material in this article are included in the article's Creative Commons licence, unless indicated otherwise in a credit line to the material. If material is not included in the article's Creative Commons licence and your intended use is not permitted by statutory regulation or exceeds the permitted use, you will need to obtain permission directly from the copyright holder. To view a copy of this licence, visit http://creativecommons.org/licenses/by/4.0/. The Creative Commons Public Domain Dedication waiver (http://creativecommons.org/publicdomain/zero/1.0/) applies to the data made available in this article, unless otherwise stated in a credit line to the data. 


\section{Main text}

\section{Disease surveys and specimen collection}

During last decade, its incidence has also been observed in Bihar state, however, the severity was not reported earlier. During a field survey at nine districts of four agroclimatic zones of Bihar, plants exhibiting typical leaf roll symptoms were arbitrarily selected and examined for the possible causes. Intriguingly, we visited farmer plots of major potato producing districts of Bihar (Zone I-Samastipur, Vaishali and Muzaffarpur; Zone II-Purnea; Zone IIIA-Sheikhpura, Nawada, Nalanda, Patna; Zone IIIB-Bhagalpur, Banka) in the month of December-January for four consecutive years (2016 to 2019). The aphid population was found very low and at the same time the incidence of PLRV was found higher i.e. up to 25\%. During the second survey in mid-February to March, the population of aphids were found higher ( 10/plant). This data reflects the severity of this disease in eastern plain zone of India before multiplication of aphid populations. The plants exhibiting typical leaf roll symptoms, chlorosis and stunting were arbitrarily selected and further examined.

\section{Serological screening for infecting PLRV in potato plant leaves}

Indirect enzyme linked immunoassay (ELISA) was performed for PLRV screening as described previously by Hobbs et al. [7]. Symptomatic and control leaves were macerated in $5 \mathrm{ml}$ extraction buffer containing $0.05 \mathrm{M}$ phosphate- buffer saline, 0.01 M sodium diethylene carbamide at $\mathrm{pH}$ 7.4. The extracts were centrifuged at $10,000 \mathrm{~g}$ for $5 \mathrm{~min}$. ELISA plate was incubated overnight at $4{ }^{\circ} \mathrm{C}$ with $100 \mu \mathrm{l}$ of supernatant. The plate was washed and blocked with skim-milk powder. Two hundred microlitre of rabbit polyclonal antibodies against PLRV-CP (Promega) (diluted 1:500 in PBS) was added to each well and incubated for $3 \mathrm{~h}$ at $37^{\circ} \mathrm{C}$. After washing, secondary antibody goat anti-rabbit immunoglobulin $\mathrm{G}$ conjugated with alkaline phosphatase (Promega) diluted 1:1000 was added to the wells and incubated for $3 \mathrm{~h}$ at $37^{\circ} \mathrm{C}$. The plate was developed with the substrate p-nitrophenyl phosphate (p-NPP) and OD at A405 nm was measured.

\section{RT-PCR analysis of viral RNA in potato}

Based on the results obtained by Indirect-ELISA, the total RNA was extracted from symptomatic leaves of potato using RNeasy Plant Mini kit (Thermo Scientific) following the manufacturer's instructions. RT-PCR was carried out using PLRV_CP gene specific primers (FP: 5'-ATGAGTACGGTCGTGGTTAGAGG-3'; RP: 5' CTA TCTGGGGTTCTGCAAAGCCAC-3'). cDNA synthesis was carried out using RT-PCR kit (Thermo Scientific).
Total reaction volume of $20 \mu \mathrm{l}$ contained RNA template, sterile water, $10 \mathrm{mM} \mathrm{dNTPs}$ mix and $50 \mu \mathrm{M}$ random nanomers. Initially, the reagents were incubated at $70{ }^{\circ} \mathrm{C}$ for $10 \mathrm{~min}$, later on, sterile water, $10 \times \mathrm{RT}$-buffer, $20 \mathrm{U} / \mu \mathrm{l}$ RNase inhibitor and $20 \mathrm{U} / \mu \mathrm{l}$ enhanced AMV-RT were added and incubated at $25^{\circ} \mathrm{C}$ for $15 \mathrm{~min}$ and $45^{\circ} \mathrm{C}$ for $50 \mathrm{~min}$. PCR was performed keeping the total reaction volume as $50 \mu \mathrm{l}$. Further, TA cloning approach was employed to sequence all the amplified $c p$ gene from different parts of infected plants. Sequence of $c p$ gene was further submitted to GenBank to get the accession number (MW027216). The details of submitted sequence are given in the "availability of data and materials" section.

\section{Results}

The infected samples were first tested through DASELISA by following the standard protocol. Further from the positive PLRV samples identified through DASELISA, total RNA was extracted from mid rib and major veins of infected leaf using RNA extraction kit and first strand cDNA was synthesized using cDNA synthesis kit (Fermentas) with respective primers. Finally, to confirm the PLRV infection, RT-PCR was performed using PLRV coat protein gene specific primers. Total RNA were extracted from all possible parts of infected plant (viz., tuber, main shoot, branched shoot and leaf) and electrophoresis analysis of RT-PCR product showed a single amplified fragment of 627 bp (Fig. 1a, b). Further, TA cloning approach was employed to sequence all the amplified $c p$ gene from different parts of infected plants.

We used same tubers from infected plant as a seed for next season cropping in controlled environment and all the results were further validated. Our consistent data of four cropping seasons indicate that these tubers act as a reservoir for these viruses and leads to the emergence of unhealthy progeny plants. From infected tubers, all the parts of progeny plants could get infected via systemic translocation of the PLRV (Fig. 1c). Because the aphid population increases exponentially during late winter season, the probability that they will encounter an infected plant is higher. Aphids acquire the PLRV into the salivary glands by feeding on infected plants and further continue to transmit the virus to healthy plants for its remaining life and completes the disease cycle (Fig. 1c). Our present study also supports the findings of Leonard and Holbrook on role of aphid in PLRV pathogenicity. Control depends solely on the use of disease-free seeds for planting [8, 9]. Farmers of indo-gangetic plain of this region import the potato seeds from neighbour states or local companies, where risk of getting unhealthy seeds is very high. As a result, the pressure of production of disease-free seed potato has become a major challenge. The most 
a

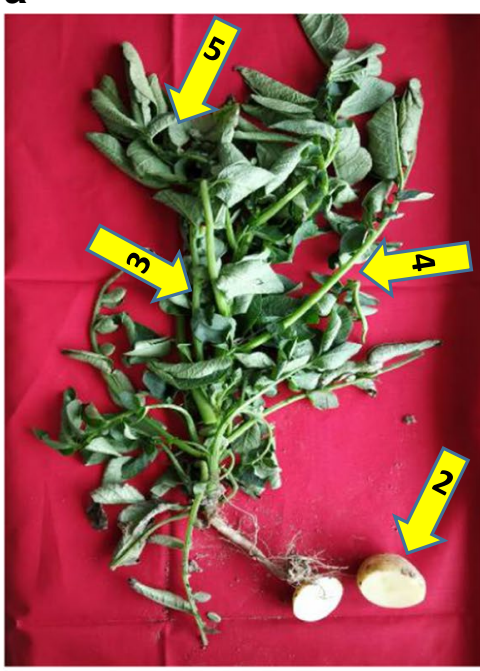

b

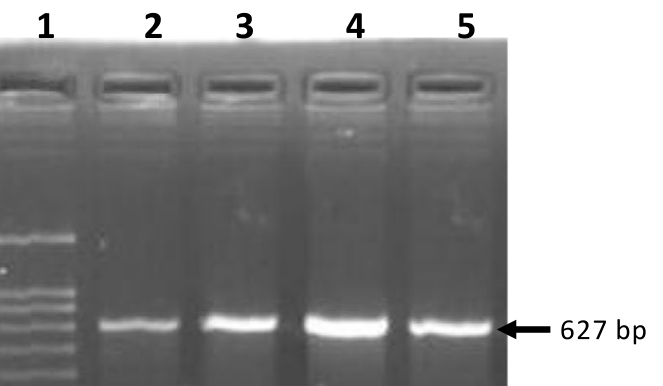

c

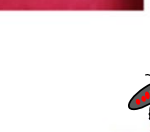

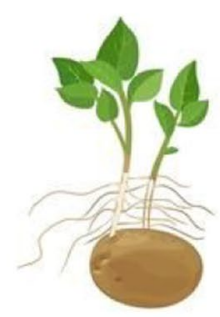

Translocation of PLRV

to emerging shoot
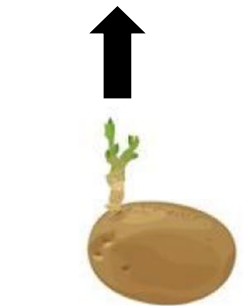

Translocation of PLRV to emerging shoot
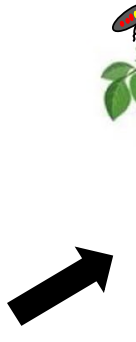

Systemic translocation and acquisition of PLRV by aphids
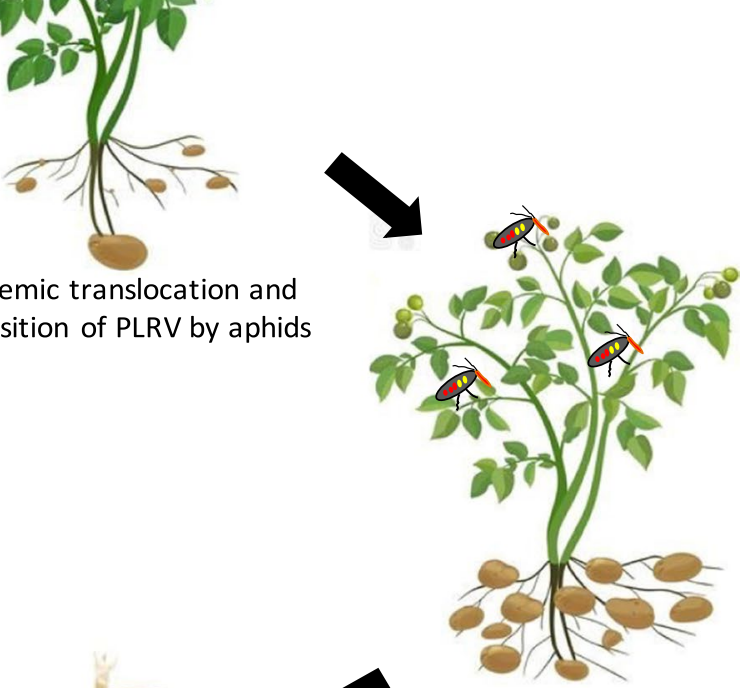

PLRV infected plants

PLRV in latent phase

Fig. 1 a Infected PLRV Plant sample. b Detection of PLRV in different parts of infected potato plant using CP specific primer (bp). Lane 1: DNA ladder; Lane 2: tuber; Lane 3: main shoot; Lane 4: branched shoot and Lane 5: leaf c Model for transmission of PLRV by collective influence of potato tuber and aphids (potato cartoons were adopted from dreamstime.com)

effective approach to manage the viral diseases is planting of healthy and virus free seed potato. The diagnosis and management of aphids are considered to be an important step towards preventing spread of the viruses in potato. Our lab is also trying to the development of a rapid, reliable and cost-effective protocol to detect simultaneously multiple virus infection in a single assay in plants and tubers (Funded by DBT, Govt. of India).

Although, the study of Wright and Bishop [6] reveals that potato tubers may act as volunteer source for PLRV and potato virus $\mathrm{X}$, but the molecular basis for PLRV 
aggravation has been not reported so far. Our present study has dissected the mechanism of transmission of PLRV by collective influence of potato tuber and aphids. As PLRV has emerged as a devastating disease in the eastern indo-gangetic plain during the last 5 years, the small and marginal farmers of this region are suffering with huge economical loss due to inadequate screening of quality of tubers. Till date, there was no reports on how PLRV spreads and affect the crop production particularly in this region, the present study validates the findings of disease biology of PLRV in order to find out an effective and timely management. Our present findings have opened up an opportunity for developing strategies for timely management of PLRV before planting and/ or before rising up the aphid populations by breaking out the chain in the peak season of aphid multiplication. Our lab is also involved in the development of kit based diagnosis of tubers for early identification and further conducting knockdown study of PLRV, which could help the scientific community in order to undertake long term management against this disease. This work will also have a significant impact on scientific community for developing PLRV resistance plant vis-a-vis agricultural sector to produce disease-free potato seed.

\section{Limitations}

- Despite all efforts so far, the detailed molecular mechanism of PLRV aggravation is poorly understood.

- Development of field based viral diagnostic kit and PLRV resistance plant are the best way to produce disease-free potato seed.

\section{Abbreviations}

PLRV: Potato leaf roll virus; CP: Capsid protein; RT-PCR: Reverse transcriptasepolymerase chain reaction.

\section{Acknowledgement}

Not applicable.

\section{Authors' contributions}

The study was conceived by TR and RRK. Molecular work was carried out by $\mathrm{KR}, \mathrm{MA}$ and JK. All authors read and approved the final manuscript.

\section{Funding}

This work was supported by grants from the Science and Engineering Research Board (SERB), Govt. of India, New Delhi (India) (File No. ECR/2016/000230). The authors wish to acknowledge the management of Bihar Agricultural University, Sabour, for their infrastructural support and creating the scientific ambience (BAU Communication No. 814/2020).

\section{Availability of data and materials}

GenBank accession number of $c p$ gene: MW027216. ATGAGTACGGTCGTGGTT AAAGGAAATGTCAATGGTGGTGTTCAACAACCAAGAAGGCGAAGAAGGCAATCC
CTTCGCAGGCGCGCTAACAGAGTTCAGCCAGTGGTTATGGTCACGGCCCCTGGG CAACCCAGGCGCCGAAGACGCAGAAGAGGAAGCAATCGCCGCTCAAGAAGA ACTGGAGTTCCCCGAGGACGAGGCTCAAGCGAGACATTCGTGTTTACAAAGGAC AACCTCATGGGCAACTCCCAAGGAAGTTTCACCTTCGGGCCGAGTCTATCAGAC TGTCCGGCATTCAAGGATGGAATACTCAAGGCCTACCATGAGTATAAGATCACA AGCATCTTACTTCAGTTCGTCAGCGAGGCCTCTTCCACCTCCTCCGGTTCCATC GCTTATGAGTTTGGCCCCATGTGCAAAGTATCATCCCTCCGGTCCTACGTCAACAAG TTCCAAATTACGAAGGGCGGCGCCAAAACTTATCAAGCGCGGATGATAAACGGG GTAGAATGGCACGATTCTTCTGAGGATCAGTGCCGGATACTGTGGAAGGGAAAT GGAAAATCTTCAGATACCGCAGGATCCTTCAGAGTCACCATCAGGGGGTGGCTT TGCAAAACCCCAAATAG.

\section{Ethics approval and consent to participate}

This article follows the experimental guidelines of the country. This article does not contain any studies involving animals or human participants performed by any of the authors.

\section{Consent to publication}

Not applicable.

\section{Competing interests}

The authors declare that they have no conflict of interest.

\section{Author details}

${ }^{1}$ Department of Molecular Biology and Genetic Engineering, Bihar Agricultura University, Sabour, Bhagalpur 813 210, India. ${ }^{2}$ Department of Plant Pathology, Bihar Agricultural University, Sabour, Bhagal pur 813210 , India. ${ }^{3}$ Department of Seed Science and Technology, Bihar Agricultural University, Sabour, Bhagalpur 813210 , India.

Received: 10 July 2020 Accepted: 31 October 2020

Published online: 10 November 2020

References

1. Palukaitis P. Resistance to viruses of potato and their vectors. Plant Pathol J. 2012:28:248-58

2. Wang B, Ma Y, Zhang Z, Wu Z, Wu Y, Wang Q, Li M. Potato viruses in China. Crop Protect. 2011:30:1117-23.

3. Kreuze JF, Souza-Dias JAC, Jeevalatha A, Figueira AR, Valkonen JPT, Jones RAC. Viral Diseases in Potato. In: Campos H., Ortiz O. (eds) The Potato Crop Springer. 2020;389-430

4. Taliansky M, Mayo MA, Barker H. Potato leafroll virus: a classic pathogen shows some new tricks. Mol Plant Pathol. 2003;4(2):81-9.

5. Kumar R, Jeevalatha A, Baswaraj R, Kumar R, Sharma S, Nagesh M. A multiplex RT-PCR assay for simultaneous detection of five viruses in potato. J Plant Pathol. 2017:99(1):37-45.

6. Wright GC, Bishop GW. Volunteer potatoes as a source of potato leafroll virus and potato virus X. Am Potato J. 1981;58(11):603-9.

7. Hobbs HA, Reddy DVR, Rajeshwari R, Reddy AS. Use of direct antigen coating and protein a coating ELISA procedure for detection of three peanut viruses. Plant Dis. 1987:71:747-9.

8. Bertschinger L, Bühler L, Dupuis B, Duffy B, Gessler C, Forbes GA, Keller ER, Scheidegger UC, Struik PC. Incomplete infection of secondarily infected potato plants-an environment dependent underestimated mechanism in plant virology. Front Plant Sci. 2017:3(8):74-82.

9. Leonard $\mathrm{SH}, \mathrm{Holbrook}$ FR. Minimum acquisition and transmission times for potato leaf roll virus by the green peach aphid. Ann Entomol Soc Am. 1978:71(4):493-5.

\section{Publisher's Note}

Springer Nature remains neutral with regard to jurisdictional claims in published maps and institutional affiliations. 